\title{
GAYA BELAJAR SISWA BERPRESTASI
}

\author{
Lita Nurbaiti ${ }^{1}$, Padyah ${ }^{2}$, Nanda Oktaviani Muzakia ${ }^{3}$ \\ Universitas Muhammadiyah Tangerang \\ litanurbaiti01@gmail.com,padyah15@gmail.com
}

\begin{abstract}
In this study the predominance of learning styles on high-achieving students in learning activities in Pondok Babar State Elementary School O6 2019 school year is auditory learning style. students use visual learning styles with the characteristics that emerge namely: high tone of voice when speaking, pay attention to one's lips movements when invited to speak, feel disturbed if the atmosphere of KBM is crowded, have difficulty remembering verbal explanations, always noting every teacher's explanation, being very careful in writing, and can always solve problems if you read first; as much as students use auditory learning styles with the characteristics that emerge namely tilted their heads to answer oral questions, lasy to take notes, when writing writing is not neat, can not read silently, recite what will be remembered, active in group discussions, happy to talk, lasy if asked to read, lazy if asked to do writing assignments, bored with reading that is too long.
\end{abstract}

Keywords: Learning Style, Student Achievement

\begin{abstract}
Abstrak: Pada penelitian ini dominasi gaya belajar pada siswa berprestasi dalam kegiatan pembelajaran di SD Negeri Pondok Bahar 06 tahun ajaran 2019 adalah gaya belajar auditori. siswa menggunakan gaya belajar visual dengan karakteristik yang muncul yaitu: nada suara tinggi ketika berbicara, memperhatikan gerak bibir seseorang ketika diajak berbicara, merasa terganggu jika suasana KBM ramai, merasa kesulitan mengingat penjelasan lisan, selalu mencatat setiap penjelasan guru, sangat berhati-hati dalam menulis, dan selalu bisa menyelesaikan soal jika membaca lebih dulu; sebanyak siswa mengunakan gaya belajar auditori dengan karakteristik yang muncul yaitu menengadahkan kepala untuk menjawab pertanyaan lisan, malas mencatat, saat menulis tulisan kurang rapi, tidak bisa membaca dalam hati, mengucap secara berulang apa yang akan diingat, aktif dalam diskusi kelompok, senang berbicara, malas jika diminta membaca, malas jika diminta mengerjakan tugas mengarang, bosan dengan bacaan yang terlalu panjang.
\end{abstract}

Kata Kunci: Gaya Belajar, Siswa Berprestasi

\section{PENDAHULUAN}

Gaya belajar didefinisikan sebagai cara manusia mulai berkonsentrasi, menyerap, memproses, dan menampung informasi yang baru dan sulit. Gaya belajar adalah satu cara yang disukai untuk memikirkan, mengolah, dan memahami informasi. Akar krisis pendidikan karena persoalan pembelajaran yang kurang efektif.

Fondatia : Jurnal Pendidikan Dasar

Volume 4, Nomor 1, Maret 2020; 28-34

https://ejournal.stitpn.ac.id/index.php/fondatia 
Salah satu unsur penting di dalamnya adalah gaya mengajar guru yang tidak cocok dengan gaya belajar peserta didik.

Thomas L.Maddem (2002) dalam bukunya "Fire Up Your Learning" mengatakan bahwa manusia pada umumnya menggunakan antara lima hingga sepuluh persen kapasitas otaknya. Jika kita mampu membuka separuh saja dari seluruh kapasitas otak, kita tidak akan menemukan lagi hambatan berbahasa dan kita tidak perlu menggunakan komputer untuk menyelesaikan soal matematika atau tugas ilmiah lainnya karena otak kita bekerja lebih cepat dari komputer.

Salah satu cara membuka potensi luar biasa yang telah terkunci rapat dalam otak adalah dengan cara memasukkan informasi ke dalam otak melalui gaya belajar yang sesuai dengan gaya mengajar.

Di bagian lain, Madden membagi lima gaya belajar melalui; (1) indera penglihatan atau visual; membaca, melihat, mengamati, visualisasi, imajinasi; (2) indera pendengaran atau auditori; mendengarkan, berbicara, berdiskusi; (3) indra peraba atau kinesterik; mengalami, mengerjakan, merasa, dan intuisi; (4) indra penciuman (olfaktori); dan (5) indra pencecap (gustatori).

Pendapat lain, Ken \& Rita Dunn dari Universitas St. John di Jamaica New York dan para pakar Pemrograman Neuro-Linguistik seperti Richard Bandler, John Grinder, dan Michael Grinder mengidentifikasi tiga gaya belajar, yakni; (1) VISUAL, yakni belajar melalui melihat sesuatu; (2) AUDITORI, yakni belajar melalui mendengar sesuatu, dan (3) KINESTETIK, yakni belajar melalui aktivitas fisik dan keterlibatan langsung", dikutip dari Rose dan Nicholl (2006) dalam bukunya "Accelerated Learning for Yhe 21 st Century".

Kebanyakan orang menunjukkan kelebihsukaan atau kecendrungan pada satu gaya belajar tertentu dibanding dua gaya lainnya. Berdasarkan hasil riset kecendrungan tersebut; $29 \%$ visual, 34\% auditori, dan 37\% kinestetik. Informasi tambahan menyatakan bahwa saat mencapai usia dewasa kecendrungan gaya belajar adalah daya visual.

Disamping itu, penelitian terhadap model gaya belajar dipengaruhi oleh fungsi dasar belahan otak, yakni otak belahan kiri dan otak belahan kanan. 
Dibuktikan tipe orang yang memperoses informasi dengan menggunakan otak kiri lebih menyukai lingkungan belajar yang sunyi, pencahayaan yang terang, dan dirancang secara formal, mereka tidak memerlukan makanan camilan, bisa belajar dengan kondisi terbaik saat sendiri atau dengan kehadiran figus yang berwenang. Sebaliknya, orang yang memperoleh informasi dengan mengunakan otak kanan lebih menyukai pengalihan kebisingan atau musik, pencahayaan redup, rancangan informal, makanan camilan, mobilitas dan interaksi dengan orang lain di tempat kerja, selama belajar atau sedang berkonsentrasi.

\section{METODE PENELITIAN}

\section{Jenis penelitian}

Jenis penelitian yang digunakan adalah penelitian kualitatif. Penelitian kualitatif merupakan sebuah proses penelitian yang mencoba untuk mendapatkan pemahaman yang lebih baik mengenai kompleksitas yang ada dalam interaksi manusia. Dengan metode kualitatif ini, penulis bisa mendapatkan data atau informasi yang lebih mendalam dan mendetail. Selain itu, pemilihan atas jenis penelitian kualitatif didasarkan atas alasan hendak memaknai sesuatu dan mencari keunikan tentang gaya belajar siswa.

\section{Subjek penelitian}

Mendefinisikan subjek penelitian sebagai sebuah benda, hal, ataupun orang yang menjadi tempat dimana data untuk variabel penelitian yang dipermasalahkan itu melekat.17 Adapun dalam hal ini subjek penelitian yang dimaksud adalah responden yang telah ditentukan sebelumnya dan merupakan bagian dari populasi yang akan diteliti. Bentuk penentuan subjek pada penelitian ini menggunakan non-probability sampling, artinya setiap angggota populasi tidak memiliki peluang/kesempatan yang sama untuk dijadikan sebagai subjek penelitian. Kemudian teknik pengambilan subjek yang digunakan adalah purposive sampling. Teknik purposive sampling merupakan teknik penentuan subyek dengan pertimbangan tertentu Dalam hal ini subjek yang dituju adalah siswa yang memiliki prestasi akademik tinggi di sekolahnya. 


\section{HASIL DAN PEMBAHASAN}

Prestasi belajar yang baik pasti ditentukan oleh bagaimana proses belajar dia untuk menuju hasil prestasi yang baik tadi. Proses atau gaya belajar pasti berbedabeda dan masing-masing gaya belajar memiliki nilai positif dan negatif begitu juga dengan dampaknya kepada orang tersebut dan di sekelilingnya. Memang betul ada pola belajar yang tidak baik dan karena itu menghasilkan prestasi belajar yang buruk tetapi kalau pola belajar baik sudah dijamin mendapat hasil yang memuaskan. Mutu pendidikan yang pun juga mempengaruhi kelangsungan pola belajar seorang murid begitu juga dengan lingkungan murid tersebut. Tetapi yang paling mempengaruhi pola belajar terhadap prestasi belajar adalah murid itu sendiri. Jika dia punya motivasi yang tinggi untuk mengembangkan pola belajar maka pola belajar tersebut akan membaik dan hasil prestasinya pun juga akan membaik. Gaya belajar dapat menentukan prestasi belajar anak. Jika diberikan strategi yang sesuai dengan gaya belajarnya, anak dapat berkembang dengan lebih baik. Gaya belajar otomatis tergantung dari orang yang belajar. Artinya, setiap orang mempunyai gaya belajar yang berbeda-beda.

Rahasia keberhasilan pembelajaran terletak pada pengenalan seseorang terhadap dirinya sendiri, kesesuaian gaya mengajar dan gaya belajar, potensinya, dan konsekwensi yang ditimbulkannya. Pengalaman di Swedia dan Selandia Baru, sekolah yang telah menerapkan gaya belajar menunjukkan perubahan, antara lain; disiplin membaik, prestasi akademik meningkat, kerjasama staf juga lebih baik, komunikasi lebih lancar, minat orang tua dalam pembelajaran meningkat. Kenyataannya, hampir semua murid yang berprestasi rendah adalah murid yang gaya belajarnya tidak cocok dengan gaya mengajar guru di sekolah.

Dalam buku Quantum Learning dipaparkan 3 modalitas belajar seseorang yaitu : "modalitas visual, auditori atau kinestetik ( $\mathrm{V}-\mathrm{A}-\mathrm{K})$. Walaupun masing-masing dari kita belajar dengan menggunakan ketiga modalitas ini pada tahapan tertentu, kebanyakan orang lebih cenderung pada salah satu di antara ketiganya".

Seorang siswa yang berprestasi memiliki gaya belajar yang lebih dominan digunakan untuk menyerap dan mengerti suatu informasi. Ada yang terdominasi indera penglihatannya sebagai alat untuk menyerap informasi, yang selanjutnya 
disebut dengan tipe visual. Pada siswa $\mathrm{Y}$, dari hasil pengamatan dan wawancara diperoleh karakteristik yang muncul yaitu merasa terganggu jika suasana KBM ramai, mencatat setiap penjelasan guru, nada suara tinggi ketika berbicara, sangat berhatihati dalam menulis, selalu bisa menyelesaikan soal jika membaca terlebih dulu, dan sulit mengingat penjelasan lisan. Pada siswa $\mathrm{D}$, dari hasil pengamatan dan wawancara diperoleh karakteristik yang muncul yaitu mencatat setiap penjelasan guru, bisa menyelesaikan soal jika membaca lebih dulu, memperhatikan gerak bibir guru saat sedang menerangkan, merasa terganggu jika suasana KBM ramai, dan siswa sangat berhati-hati dalam menulis.

Ada yang terdominasi indera pendengarannya untuk memasukkan informasi yang disebut tipe auditori. Pada siswa A dari hasil pengamatan dan wawancara diperoleh karakteristik yang muncul yaitu menengadahkan kepala untuk menjawab pertanyaan lisan, mengucap secara berulang apa yang akan diingat, bosan dengan bacaan yang sedikit panjang, malas mencatat, tulisan kurang rapi, aktif dalam diskusi kelompok, malas jika diminta membaca. Pada siswa $\mathrm{Y}$ dari hasil pengamatan dan wawancara diperoleh karakteristik yang muncul yaitu menengadahkan kepala untuk menjawab pertanyaan lisan, malas mencatat, tulisan kurang rapi, bosan dengan bacaan agak panjang, tidak bisa membaca dalam hati, mengucap secara berulang apa yang baru ia dengar, aktif dalam kegiatan kelompok, kurang pandai mengerjakan tugas mengarang. Pada siswa $\mathrm{P}$ dari hasil pengamatan dan wawancara diperoleh karakteristik yang muncul yaitu tidak bisa membaca dalam bisa membaca dalam hati, senang berbicara.

Ada juga yang terdominasi oleh indera peraba, pembau, perasa, dan gerak yang disebut tipe kinestetik. Gaya belajar kinestetik dimiliki oleh satu siswa yaitu siswa I. Pada siswa I dari hasil pengamatan dan wawancara diperoleh karakteristik yang muncul yaitu tidak dapat duduk diam dalam waktu lama, mudah dalam mengingat petunjuk praktek, senang dengan kegiatan praktek, melakukan dengan baik materi yang akan dipraktekkan, suka menyentuh segala sesuatu yang dijumpai. Berdasarkan uraian di atas, karakteristik gaya belajar kinestetik siswa berprestasi dapat dipersentasekan sebagai berikut, 
Pada gaya belajar visual, terdapat satu karakteristik yang dikemukakan oleh Gunawan, yaitu nada suara tinggi ketika berbicara. Karakteristik tersebut ditunjukkan oleh siswa Y. Karakteristik yang dikemukakan oleh Musrofi, yaitu merasa terganggu jika suasana KBM ramai. Karakteristik tersebut ditunjukkan oleh siswa Y dan D. karakteristik yang dikemukakan Edia, yaitu memperhatikan gerak bibir seseorang ketika diajak berbicara dan sulit mengingat penjelasan lisan. Kedua karakteristik tersebut ditunjukkan oleh siswa D. karakteristik yang dikemukakan Efendi yaitu sangat teliti dan detail, terlihat saat menulis di buku catatan. Karakteristik tersebut ditunjukkan oleh siswa $\mathrm{Y}$.

Pada gaya belajar auditori, karakteristik yang dikemukakan Gunawan, yaitu mengakses informasi dengan menengadahkan kepala dan mengingat informasi melalui suara. Karakteristik tersebut ditunjukkan oleh siswa A, Karakteristik yang dikemukakan Musrofi, yaitu cenderung meremehkan tulisan sehingga mengalami kesulitan dalam menulis, mengucap secara berulang apa yang akan diingat, dan berusaha menghindari deskripsi yang panjang lebar. Dalam hal kesulitan menulis, bisa berakibat tulisan menjadi kurang rapi. Karakteristik tersebut ditunjukkan oleh siswa A, P, dan F. Karakteristik yang dikemukakan oleh Edia, yaitu kurang baik dalam mengerjakan tugas mengarang, sehingga cenderung malas mengerjakan. Karakteristik tersebut ditunjukkan oleh siswa P. Karakteristik gaya belajar auditori yang dikemukakan oleh Effendi, yaitu merasa kesulitan dalam menulis yang menyebabkan rasa malas sehingga hasil tulisan kurang rapi dan suka berbicara panjang lebar. Karakteristik tersebut ditunjukkan oleh siswa A, F, dan P.

Pada gaya belajar kinestetik, karakteristik yang dikemukakan Musrofi yaitu mengingat dengan baik apa yang dipraktekkan dan tidak dapat duduk diam dalam waktu lama. Karakteristik tersebut semuanya ditunjukkan oleh siswa I. Karakteristik yang dikemukakan Edia (2011) yaitu suka menyentuh segala sesuatu yang dijumpai dan sulit berdiam diri. Kedua karakteristik tersebut ditunjukkan oleh siswa I. Karakteristik yang dikemukakan oleh Effendi yaitu suka menyentuh seseorang untuk mendapat perhatian, yaitu pada siswa I, 


\section{KESIMPULAN}

Pada penelitian ini dominasi gaya belajar pada siswa berprestasi dalam kegiatan pembelajaran di SD Negeri Pondok Bahar 06 tahun ajaran 2019 adalah gaya belajar auditori. siswa menggunakan gaya belajar visual dengan karakteristik yang muncul yaitu: nada suara tinggi ketika berbicara, memperhatikan gerak bibir seseorang ketika diajak berbicara, merasa terganggu jika suasana KBM ramai, merasa kesulitan mengingat penjelasan lisan, selalu mencatat setiap penjelasan guru, sangat berhati-hati dalam menulis, dan selalu bisa menyelesaikan soal jika membaca lebih dulu; sebanyak siswa mengunakan gaya belajar auditori dengan karakteristik yang muncul yaitu menengadahkan kepala untuk menjawab pertanyaan lisan, malas mencatat, saat menulis tulisan kurang rapi, tidak bisa membaca dalam hati, mengucap secara berulang apa yang akan diingat, aktif dalam diskusi kelompok, senang berbicara, malas jika diminta membaca, malas jika diminta mengerjakan tugas mengarang, bosan dengan bacaan yang terlalu panjang; dan siswa menggunakan gaya belajar kinestetik dengan karakteristik yang muncul yaitu suka menyentuh segala sesuatu yang dijumpai, senang dengan kegiatan praktek, mengingat dengan baik apa yang dipraktekkan, tidak dapat duduk diam dalam waktu lama, mudah dalam mengingat petunjuk praktek, melakukan dengan baik materi yang dipraktekkan. Saran dalam penelitian ini ditujukan kepada siswa, orang tua, dan guru. Siswa hendaknya memanfaatkan gaya belajar yang dimiliki agar memperoleh hasil belajar yang lebih baik. Orang tua hendaknya selalu memberi perhatian dan motivasi kepada siswa serta membantu memanfaatkan gaya belajar yang dimiliki. Guru hendaknya menggunakan gaya mengajar yang sesuai dengan gaya belajar siswa.

\section{DAFTAR PUSTAKA}

De Porter, Bobbi dan Hernacki, Mike. 2004. Quantum Learning. Jakarta: Kaifa

Didik. (2009). Gaya belajar kinestik . diperoleh 2 desember 2019. Dari http://didikz888.wordpress.com/tag/gaya-balajar-kinestetik/.

Hidayana, Herma. 2009. Pengaruh Gaya Belajar terhadap Prestasi Belajar Siswa

Musrofi, M. (2010), melesatkan prestasi akademik siswa. Yogyakarta: PT. Pustaka Insan Madani. 